A.Ü. Türkiyat Araştırmaları Enstitüsü Dergisi Sayı 39, Erzurum $2009 \sim 101$

Prof. Dr. Hüseyin AYAN Özel Sayısı

\title{
ŞEYHOĞLU MUSTAFA: HURŞÎD-NÂME (HURŞîD Ü FERAHŞÂD) *
}

İsmail AVCI ${ }^{* *}$

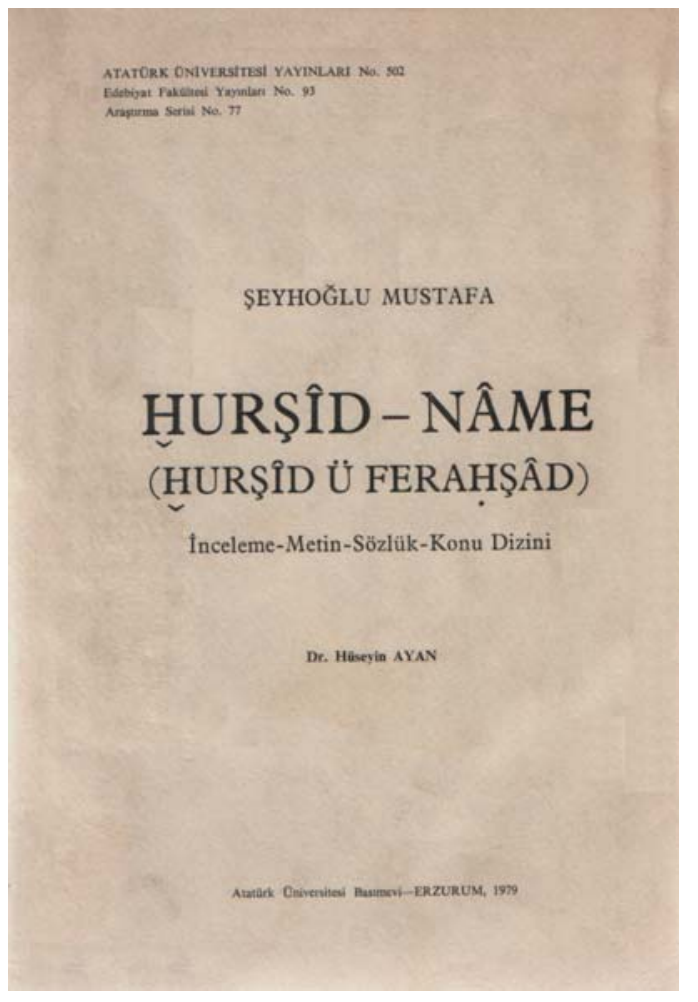

Bu nazmı isteye 'âkil olanlar Nite kim mey hoşın bilür içenler

Çü cânum ol şerâbı nûş kıldı Yüregüm kopdı göñüm cûş kıldı Açılsun güllere 'arz it bahâruñ Ki bülbüllere kala yâdigâruñ

Şeyhoğlu Mustafa, miladi 1387 yılında, yaşı elliye dayandığ 1 sıralarda tamamladığı Hurşîdnâme'nin (Hurşî̀ ü Ferahşâd, Şehristân-1 'Uşşâk) yazılış sebebini açıklarken yukarıdaki beyitlere yer vererek eserin okuyacaklara bir yadigâr kalmasını arzu ettiğini dile getirir. Şeyhoğlu'nun bu misraları söylemesinden 592 y1l sonra, ona kulak veren, bıraktığı yadigârı hurşîd misali ayân eden, okuyan, bu nazmı isteyen, 'âkil olan, mey hoşın bilürlerden değerli ilim adamı Hüseyin Ayan, eserin tenkitli metnini hazırlayıp inceleyerek ilim âlemine sunmuştur. $\mathrm{Bu}$ yazıda, Hüseyin Ayan'ın hazırladığı eser tanitılacaktır.

Eser; Önsöz, kısa bir Giriş (s. 1-4) ve dört Bölümden oluşmaktadır. İlk üç Bölüm (s. 5-118) müellife ve eserin incelenmesine ayrılmış, bunun hemen

\footnotetext{
* Hüseyin Ayan, Şeyhoğlu Mustafa, Hurşîd-nâme (Hurşîd ü Ferahşâd), İnceleme-Metin-SözlükKonu Dizini, Atatürk Üniversitesi Edebiyat Fakültesi Yay., Erzurum 1979, IV+533 s.

** Balıkesir Üniversitesi Necatibey Eğitim Fakültesi Arş. Gör.
}

TAED 39, 2009, 101-111 
ardından Sonuç (s. 119-122) ve Bibliyografya (s. 123-127) verildikten sonra Şeyhoğlu'nun bir başka eseri olan ve edebî kişiliğinin ortaya konulması noktasında faydalanılan Kenzü'l-Küberâ ve Mihekkü'l-Ulemâ'dan iki varağın fotokopisi eklenmiştir. $\mathrm{Bu}$ iki varaklık fotokopiden sonra Transkripsiyon Işsâretleri gelmektedir. Tenkitli metnin yer aldı̆̆ Dördüncü Bölümden (s. 129427) sonra ise bir Sözlük (s. 429-528) ve Konu Dizini (s. 529-533) yer almaktadır.

H. Ayan, Önsözde eser üzerinde çalışmasının gayesini şöyle açıklar: "Bu araştırma ve incelemenin gayesi, XIV. yüzyıl Türk Edebiyatının ünlü siması Şeyhoğlu Mustafa'nın hayatını, edebî kişiliğini, özellikle bugüne kadar yapılmamış bulunan Hurşî̀-nâme (Hurşî̀d ü Ferahşâad-Şehristân-l 'Uş̧̧âk) mesnevîsinin tenkidli metnini hazırlayı inceleyerek, müellifi ve eserleri hakkında yeni bilgiler vermektir." (s. I).

Eserin Giriş kısmında, kısaca Türk edebiyatında mesnevi geleneğinin Hurşîd-nâme'ye gelinceye kadarki seyri üzerinde durulmuştur.

Birinci Bölüm "Şeyhoğlu'nun Hayatı ve Edebî Kişiliği”" başlığını taşımaktadır. Alt başlıklar ise "Şeyhoğlu'nun Hayatı", "Şeyhoğlu'nun Edebî Kişiliğii", "Şeyhoğlu'nun Eserleri", "Hurşîd-nâme Metninin Kurulması" ve "Metni Kurmada Tutulan Yol" şeklinde düzenlenmiştir.

Şeyhoğlu'nun hayatı hakkında verilen bilgilere göre doğum yılı yaklaşık olarak miladi 1341'dir. Ancak nerede doğduğu bilinmemektedir. Saray çevresine yakın soylu bir aileden gelmektedir. Germiyan (Kütahya) edebî muhitinde yetişmiştir. H. Ayan bu kısımda, müellifin adı etrafında tereddüt ve şüphelerin olduğunu, yapılan bazı çalışmalarda Sadrüddin adının/lakabının da geçtiğini belirtir. Ancak, ihtiyatı elden bırakmamak kaydıyla, Sadrüddin adının lakap olarak da düşünülebileceğini söyler. Ona göre, eğer Mustafa ve Sadrüddin isimleri aynı şahıs üzerinde toplanabilirse XIV. yüzyılın ikinci yarısında, Ahmedî'den önce şöhrete ulaşan ve bu şöhretini XVI. yüzyılda da sürdüren, Marzubân-nâme, Kâbûs-nâme tercümelerinin; Kenzü'l-Küberâ ve Mihekkü'l'Ulemâ'nın ve Hurşîd-nâme'nin sahibi olan edebî yönü kuvvetli bir kişilik karşımıza çıkacaktır.

"Şeyhoğlu'nun Edebî Kişiliğị" alt başlığında ise Ahmedî ve Şeyhoğlu Mustafa arasındaki rekabet ve münakaşa söz konusu edildikten sonra, müellifin Türkçe karşısındaki tutumu üzerinde durulmuştur. Burada örnek beyitlerle verilen bilgilere göre müellif, Türkçeden şikâyet etmektedir ve edebî bir eserin Türkçe olarak yazılmasındaki güçlüklerden bahsetmektedir. H. Ayan, şairin bu tavrı için; "Türkçenin bütün inceliklerine vâkıf olan Şeyhoğlu'nun bu şikâyetlerini anlamak güçtür." dedikten sonra, "Bu şikâyetleri haklı bulmamakla berâber, buna rağmen, muhalled bir eseri Türkçe yazmasl, onu affettirmeye yeter 


\section{A.Ü. Türkiyat Araştırmaları Enstitüsü Dergisi Sayı 39, Erzurum 2009 ～ 103 〜}

Prof. Dr. Hüseyin AYAN Özel Sayısı

de artar da!’ (s. 11-12) değerlendirmesini yapar. Müellifin edebî yönü üzerinde durulurken onun kimlerden etkilendiği de konu edilir. H. Ayan burada, İran edebiyatının önde gelen isimlerini sayar ve özellikle bunlardan Ferîdüddîn Attâr ve Senâ̂̂'nin, Şeyhoğlu'nun edebî kişiliğinin oluşumunda önemli rol oynadıklarını belirtir. Araştırmacı, Şeyhoğlu'nun bu iki ismi anmasını, kendisini onlarla mukayese etme arzusunda olduğu şeklinde yorumlar. $\mathrm{Bu}$ kısımda, müellifin eserini övdüğü ve kendisiyle ilgili değerlendirmeler yaptığı beyitlere de yer verilmiştir. H. Ayan, Şeyhoğlu Mustafa'nın Kenzü'l-Küberâ adlı eserinden verdiği örnek metinlerden hareketle de bazı değerlendirmelerde bulunur ve "... Şeyhoğlu, secili nesrin üstâdlarl arasında yer alacak kadar güçlü bir nâsirdir.” (s. 15) der. Yazar, şairin edebî kişiliğinin, şiire hâkimiyetinin Hurşîd-nâme'de geçen gazellerinden örnekler verilerek de ortaya konulabileceğini, ancak bu değerlendirmelerin, onun henüz ele geçmeyen gazellerinin bulunup incelenmesiyle ve diğer eserlerinin tenkitli metinlerinin hazırlanmasıyla daha isabetli olacağını söyler. Bu bahis; "Türkçenin edebiyat ve ilim dili olarak gelişmesinde, Şeyhoğlu'nun eşsiz gayretleri görmezlikten gelinemez. Onun, Türk Edebiyatının gelişmesinde gösterdiği gayreti nazımda Hurşî̀d-nâme ve nesirde de Kenzü'l-Küberâ ve Mihekkü'l-'Ulemâ adl eşsiz eserleri ispat etmeye yeterli birer delil olarak ortadadır." (s. 16) cümleleriyle sonlandırılmıştır.

"Şeyhoğlu'nun Eserleri” başlığı altında, çalışmanın asıl konusu olması sebebiyle Hurşîd-nâme'nin sadece 7903 beyitlik bir mesnevi olduğu belirtilip müellifin diğer üç eseri tanıtılmıştır. Tanıtılan ilk eser Kenzü'l-Küberâ ve Mihekkü'l-'Ulemâ'dır. Kenzü'l-Küberâ, Şeyh Necmüddini Râzî veya Necmüddin Dâye'nin Mirsâdü'l-'İbâd Mine'l-Mebdei İle'l-Me'âd adlı beş baplık Farsça eserinin son babının pek çok ilave ve değişikliklerle Türkçeye tercümesidir. Eser, Şeyhoğlu'ndan önceki şairlerin şiirlerinden örnekler ihtiva etmesi bakımından önemlidir. H. Ayan, Kenzü'l-Küberâ'nın XV. yüzyıl müelliflerinden Sinan Paşa'nın Tazarru'ât'ı için bir öncü olduğu kanaatindedir. Burada, eserin başından ve sonundan alınmış örnek kısımlar da mevcuttur. Diğer iki eser ise kısaca üzerinde durulan Marzubân-nâme Tercümesi ve Kâbûs-nâme Tercümesi'dir. H. Ayan, yukarıda da belirtilen Sadrüddin Şeyhoğlu ve Mustafa Şeyhoğlu ikiliğine burada da dikkati çekmiştir.

"Hurşîd-nâme Metninin Kurulması" kısmında, eserin tenkitli metni hazırlanırken kullanılan Berlin, Süleymaniye (Hamidiye), Manisa (Muradiye) ve Paris nüshaları tanıtılmıştır. Ayrıca, yurt dışındaki kütüphanelerin kataloglarında adına rastlanan, ancak elde edilemeyen altı nüshasının olduğu belirtilmiştir. "Metni Kurmada Tutulan Yol" başlığı altında ise genel olarak tenkitli metnin 
hazırlanması, karşılaşılan problemler ve nelere dikkat edildiğinden bahsedilmiştir.

Eserin İkinci Bölümü "Hurşîd-nâme'nin İncelenmesi" ana başlığını taşımaktadır. Alt başlıklar ise şöyledir: "Hurşîd-nâme'deki Nazım Şekilleri", "Hurşîd-nâme'de Kullanılan Vezinler", "Hurşî̂d-nâme'nin Konusu", "Hurşîdnâme Konusunun İran Edebiyatı İle Olan İlgisi", "Hurşîd-nâme Kahramanlarının Tarihî-Efsânevî Kişilikleri", "Hurşîd-nâme'de Savaş Araçları ve Strateji", "Hurşîd-nâme'de Eğitim ve Öğretim", "Hurşîd-nâme'de Hurâfelerin İzleri", "Hurşîd-nâme'de Gelenekler", "Hurşîd-nâme'de İslâm Kültürü" ve "Hurşîdnâme'de Aşk".

Hüseyin Ayan, inceleme kısmının ilk cümlelerine, Hurşîd-nâme'nin şekil itibarıyla mükemmel bir mesnevi olduğunu belirterek başlar ve şu değerlendirmeyi yapar: "Şair, Hurşî̀d ü Ferahşâd'da, o zamana kadar bir mesnevide bulunması belirlenmiş hususların hiçbirisini ihmal etmemiştir. Şeyhoğlu Mustafa, Şehnâme'den aldiğı epizot ve motiflere başka kaynaklardan ve özellikle Türk tarihi ve geleneklerinden ilâveler yaparak bunlar yerli yerine koymuş, olayın bütün inceliklerini nazımla söylemiş ve bu uğurda büyük emek harcamıştır. Eserin hacmi (7903 beyit) yanında, her beytine gösterilen itina ve ihtimam da bizim bu yargımıza hak verdirecek niteliktedir." (s. 31). Bu cümlelerden sonra "Hurşîd-nâme'deki Nazım Şekilleri” alt başlı̆ğıla eserdeki nazım şekilleri üzerinde durulmuştur. Buna göre, eserde asıl nazım şekli olan mesnevinin yanında, tercî-i bend ve gazeller de yer almaktadır.

"Hurşî̂d-nâme'de Kullanılan Vezinler" alt başlığında, mesnevinin mefâ' îlün mefâ'îlün fe'ûlün kalıbıyla yazıldığı, bunun yanında on muhtelif aruz kalıbının kullanıldığ 1 belirtilmiş ve eserde farklı nazım şekilleri ve vezinlerinin kullanımıyla ilgili olarak Şeyhoğlu'nun başarısına şöyle vurgu yapılmıştır: “... bir büyük mesnevîde, vak'anın akışına durgunluk vermeden, sadetten çıkmadan arûzun kolay sayılmayan kalıplarını denemek, nazım tekniğine olduğu kadar, dile de hâkimiyeti gösterir. Şeyhoğlu'nun şiirdeki üstün dehâsının belgeleri arasında bu hususu da zikretmek yerinde olur.” (s. 33). Bu kısmın sonunda yirmi üç gazel ve bir tercî-i bendde kullanılan aruz kalıpları toplu olarak verilmiştir.

H. Ayan, "Hurşîd-nâme'nin Konusu" başlığıyla, İran şahı Siyâvuş'un kızı Hurşîd ile Mağrip sultanının oğlu Ferahşâd'ın aşk hikâyesini on sayfada özet olarak vermiştir. Hikâye, çalışmanın merkezini teşkil ettiğinden, verilen özetin özetini buraya alıyoruz. Hikâye şöyledir:

İran şahı Siyâvuş'un Hıtâyî Ay Hatun'dan bir kızı dünyaya gelir. Padişah erkek beklerken çocuk kız olunca çok üzülür. Âdet olduğu üzere müneccimleri toplayıp kızının talihine baktırır. Müneccimler "İlk altı günde bu kız için çok tehlike var, altı günü atlatırsa on altı yaşında 


\section{A.Ü. Türkiyat Araştırmaları Enstitüsü Dergisi Sayı 39, Erzurum $2009 \sim 105 \sim$ Prof. Dr. Hüseyin AYAN Özel Sayısı}

bu kızın güzelliği yüzünden ülkede bir fitne kopacak, taht tehlikeler geçirecek, çok insan ölecek.” derler. Bunları duyunca korkan padişah çocuğu öldürtmek ister. Ancak annesi buna razıymış gibi görünüp yeni ölmüş bir çocuğu Hurşîd'in yerine defnettirir, Hurşîd'i de gizlice Dârü'l-Melek kalesine gönderir. Çocuğun okuma çağ 1 gelince Pîr Muallim görevlendirilir ve Hurşîd dokuz yıl boyunca Pîr Muallim'in elinde bütün ilim ve fenleri tahsil eder. Bu arada padişah çocuğun gizlice büyütülmekte olduğunu öğrenir, öfkesinden deliye döner. Yanına dört muhafizını alır ve kaleye gider. Muhafizlarını Hurşîd'i getirmeleri için kale içine gönderir. Ancak hiçbirinden ses çıkmaz ve kendisi içeriye girer. Her şeyden habersiz yatağında yatan Hurşî̉ uyanır, karşısında yalın kılıç bekleyen babasını görür. Kızının güzelliği karşısında hareketsiz kalan padişah, gönderdiği muhafızların da bu güzellik karşısında baygın hâlde yerde yattıklarını görür. Biraz kendisine gelir, kızına iyi muamele etmeye çalışır. Hurşîd ve beraberindekileri Cemâbâd'a getirir. Hıtâyî Ay Hatun kızını görünce bayılır, padişah eşine kızının yaşamasını sağladığı için teşekkür eder, müneccimlere de inanmadığını söyler. Bundan sonra neşeli günler başlar... Hurşîd babasından ricacı olup sarayın bahçesinde bir köşk yaptırır ve günlerini bu bahçede ve köşkte geçirir.

Padişahın dört sadık muhafızı neden sonra kendilerine gelirler ve feryatlar kopararak yollara düşerler. Cemâbâd yakınlarında içlerinden biri dayanamayarak ölür, ona bir mezar yaparlar ve mezar taşına da aşktan öldüğüne dair üç beyit yazarlar. Sonra muhafizlar birbirlerinden ayrılırlar; biri doğuya, biri batıya, biri de Mısır tarafına doğru yönelir. Günlerden bir gün Hurşîd dadısına biraz dışarıda dolaşmak istediğini söyler. Dadısı bir gece onu gizli bir geçidi kullanarak şehirden dışarı çıkarır. Dolaşırlarken aşkından ölen muhafızın mezarına rastlarlar. Hurşîd bu sadık âşı̆̆ına bir türbe yaptırmak ister ve bir rüya uydurur. Buna göre rüyasında Hızır İlyas'ı görmüş, Hızır İlyas kendisine burada bir türbe yaptırmasını istemiştir. Babası rüyayı gerçek sanır ve türbe yapılır, türbenin adı da Hızır İlyas olur.

Mağrip tarafına giden muhafızlardan Âzâd, yaşadığı macerayı Mağrip sokaklarında anlatır, herkes deli diye onu alaya alır. Bu hikâye saraya kadar ulaşır. Mağrip sultanının oğlu Ferahşâd bir gün sarayında eğlenirken içeri Âzâd girer, ondan Hurşîd'in kimliğini öğrenir, hemen âşı olur. Âzâd'a kendisine yoldaşlık etmesini ister ve yollara düşerler. Yolda dağla, taşla, kurtla, kuşla konuşan ve vahşi hayvanlarla arkadaşlık eden Mecnun'a rastlarlar. Mecnun aşkı dile getiren şiirler söyler, bunları dinleyen Ferahşâd ve Âzâd daha hızlı yol almaya başlarlar. Atları bu hıza dayanamaz, erzakları biter, aç kalırlar. Zelil, sefil yollarda sürünürler. Günlerden bir gün Hızır İlyas türbesine gelirler. Türbenin bekçisi buranın bir dilek yeri olduğunu, dilekleri varsa dilemelerini söyler. Türbeyi hayranlıkla seyreden Ferahşâd mezarın başındaki beyitleri okuyunca türbeyi yaptıranın Hurşîd olduğunu anlar. Kim olduklarını soran bekçiye de derviş olduklarını, yıllardır Mescid-i Aksâ'da ibadet ettiklerini, gece rüyalarında boz atlı Hızır'ı gördüklerini ve Hızır'ın onlara Cemâbâd yakınlarında bir makamım var, oraya gidin ve bundan sonra orada kalın dediğini söylerler. Bu hikâye derhâl Hurşî̀d'e ulaştırılır. Hurşîd bunu duyunca görmeden Ferahşâd'a âşık olur. Onlara yemek gönderir, yakından ilgilenir. Ferahşâd'ın Hurşî̉'i görme arzusu da gittikçe şiddetlenir. Dili çözülür, şiir söylemeye başlar, söylediklerini de Âzâd yazar. Bu sırada Hurşîd'in lalası gelir, bunları Hurşîd'e götürür. Hurşîd şiirleri okuyunca Ferahşâd'a âşı olduğunu söyler, şiire şiirle karş1lık verir. Bundan sonra Hurşîd'in köşkünde gizli eğlenceler tertip edilmeye başlanır. Aşkları gittikçe artar. Bu zamana kadar yüzünü bir peçeyle örten Hurşîd bir gece perdeyi kaldırır. Ferahşâd bayılır, gülsuyuyla ayıltırlar.

Hurşîd ile Ferahşâd bu sevginin sefasını sürerken maşrık yönüne giden, adı Siyâh ve kendisi de kara olan köle Hıtây ülkesine varır ve orada 1klık (saz) çalan bir köseyle karşılaşır. Sazın nağmelerinden aşkı coşar, bayılır. Ayılınca kösenin ayaklarına kapanır ve kendisine 1 klık çalmayı

TAED 39, 2009, 101-111 


\section{～ 106 ～～ì. AVCI: Şeyhoğlu Mustafa: Hurşîd-nâme (Hurşîd ü Ferahşâa)}

öğretmesini ister. Siyâh, kısa zamanda 1klık çalmasını öğrenir ve ünü bütün ülkeye yayılır. Hıtây ülkesinin padişahı Boğa Han, Siyâh'ın sarayına getirilmesini emreder. Ancak Siyâh'1 getirmeye gidenler geri gelmez. Çünkü iklığın sesini duyanlar mest olup orada kalmaktadırlar. Boğa Han veziri Turumtay'ı da yanına alarak yola düşer. Çağlayanların bulunduğu, kuşların cıvıldadığı bir yerde Siyâh'1 1klık çalarken bulurlar. Boğa Han sazın sesini duyunca çok duygulanır, 1klıkçıyı saraya götürür. Siyâh başından geçenleri anlatır. Boğa Han anlatılanları dinleyince Hurşîd'e görmeden âşık olur. Veziri Turumtay’ı Hurşîd'i istemek üzere Acem mülküne gönderir. Turumtay, Cemâbâd'a gelir, Boğa Han'ın yazdığı mektubu Siyâvuş'a verir. Mektupta istekle tehdit bir aradadır. Olumsuz cevap alınınca da Boğa Han kendisine bağlı ülkelere iki yıllık bir savaş için bitikler yazar. 300.000 atlının da olduğu muazzam bir ordu hazırlanır ve İran'a doğru yola çıkar. Siyâvuş vezirlerini toplar, onlarla ne yapılması gerektiğini konuşur, 60.000 kişilik bir ordu hazırlanır. Vezirlerden bazıları böyle bir orduyla Boğa Han'a karşı durmanın akıl işi olmayacağını söylerler, Hurşîd'i verelim kurtulalım derler. Bu arada Boğa Han, Sırtak’1 5.000 atlı ve 3.000 erle tekrar elçi olarak gönderir. Siyâvuş gelenleri hoş karşılar, ikramlarda bulunur. Aynı zamanda askerlerini teftiș eder. Bunu yaparken de önünden ilk geçen askerleri arkadan dolaștırıp tekrar geçirerek hileli bir yola başvurur. Bunu gören Sirtak askerlerin çokluğundan korkuya kapılır. Siyâvuş'un askerlerinden bir grup Boğa Han'ın öncü kuvvetini bir gece gafil avlayıp kırar, ayrıca elçiyi de azarlayıp saçını sakalını yoldurur, burnunu kırdırır ve Boğa Han'a gönderir. Sırtak gelince Boğa Han'a olanları anlatır. Bunun üzerine Boğa Han kızgınlıkla Cemâbâd üzerine saldırır. Şiddetli bir savaş cereyan eder. Savaşın üçüncü günü, Siyâvuş'un en ünlü savaşçısı Zaygam, Boğa Han'ın askerlerince ele geçirilir. Siyâvuş danışma meclisini toplar. Meclis Hurşîd'in verilmesi ve savaşın bitirilmesi kararına varır ve karar Hurşîd'e iletilir. Hurșîd, bir rüya gördüğünü ve ertesi günü yapılacak savaşta Boğa Han'ın öldürüleceğini söyleyip babasını oyalar. Bir tuzak hazırlar, hemen Boğa Han'a bir mektup yazar, aslında kendisini çok sevdiğini ama ailesinin razı olmadığını, bir savaşçı gibi zırh giyip kendisine geleceğini söyler. Dediği gibi yapar ve ertesi günü askerlerin arasında sıyrılıp Boğa Han'a gelir. Yüzünü açar, onun güzelliğini gören ve yarı baygın hâle gelen Boğa Han'1 öldürür. Ferahşâd'a da Boğa Han'1 babasına ben öldürdüm demesini, işlerinin böylece kolaylaşacağını söyler. Bu arada padişahın öldürüldüğünü duyan askerler dağılır. Âzâd'la Hurşîd'in zırhını giyen Ferahşâd Turumtay'ı yakalarlar. Siyâvuş, Turumtay'ın asılmasını, ele geçirilen hazinenin de onu yakalayana verilmesini emreder. Hazineye sahip olan Ferahşâd bunları Âzâd'a bağışlar. Yedi gün yedi gece bayram yapılır, Boğa Han'ı öldüren Ferahşâd, Siyâvuş'un katında büyük itibar görür, evlatlığa kabul edilir ve Hurşîd kendisine layık görülür. Hitâŷ Ay Hatun da bunu uygun bulur. Ancak vezirler "Cemşid aslından gelen birine Hurşîd verilir mi?" deyip karşı çıkarlar, padişah da onlara hak vermek zorunda kalır. Ferahşâd bunu öğrenince aslını ortaya koyar ve Mağrip sultanının oğlu olduğunu açıklar. Ancak vezirler yine karşı çıkarlar, eğer Mağrip sultanının oğluysa babasının hazinesindeki şebçerağlardan birini getirsin derler. Siyâvuş kabul eder ve Ferahşâd'a "Şebçerağı getir, kızı götür." der. Ferahşâd, Hurşîd'le vedalaşır, Âzâd'la yola koyulur. Türlü güçlüklerden sonra memleketine varır. Sultan oğlunun dönmesine çok sevinir. Vezirlerini toplar ve padişahlığı oğluna devretmeyi düşündüğünü söyler, vezirler de uygun bulurlar. Ancak Ferahşâd özür beyan edip İran şahının kızına âşık olduğunu ve kızı alabilmek için hazinede saklanan şebçerağlardan birinin kalın (çeyiz) olarak istendiğini söyler. Babasına çok yalvarır, ancak razı edemez. Sultan kaçıp gitmesin diye de Ferahşâd'ı hapse atar. Ferahşâd hapiste Hurşîd'i düşünür, Hurşî̉ Ferahşâd'ın yolunu gözler, günler geçer...

Siyâvuş'un muhafızlarından üçüncüsü Kâfûr, aylarca yürüdükten sonra Çin ülkesindeki Nigâristan-1 Çîn adındaki șehre varır. Her tarafın resimlerle süslenmiș olduğunu görür ve resimlere bakınca Hurşîd'i hatırlar. Hurşî̀d sözü ağzından çıkar çıkmaz bayılır. Bunu gören halktan kimisi ona deli der, kimisi âşık der. Kâfûr ayılınca resimleri yapan ressamın yanına koşar ve ondan resim yapmasını öğrenir. Kısa zamanda, Hindistan'da Mani'nin şöhreti neyse, Çin'de de Kâfûr'un adı o

TAED 39, 2009, 101-111 


\section{A.Ü. Türkiyat Araştırmaları Enstitüsü Dergisi Sayı 39, Erzurum 2009 ～ 107 Prof. Dr. Hüseyin AYAN Özel Sayısı}

kadar meşhur olur. Bir bez parçasının üzerine Hurşîd'in resmini çizer ve gizli gizli ona bakıp kendisini avutur. Bir gün yine resme bakarken şiddetli bir rüzgâr çıkar ve resmi uçurur. Sarayın bahçesinde cennet gibi bir köşede eğlenen Mısır sultanı Tûs'un oğlu Behrâm, ağaçların dalları arasında bir şey görür. Hemen o şeyi aldırır, bir de bakar ki dünyada eşi benzeri bulunmayan bir güzelin resmi! Birden bayılır. Babası Tûs onu teselli etmeye çalışır. Behrâm, "Kimine mektubu Hüdhüd, kimine yel getirir, bugün Süleyman benim, Belkıs'1 bulmam gerekir." der. Tûs oğluna "Niyetin Siyâvuş'un kızı Hurşîd ise babası onu sana vermez, verseydi Boğa Han'a verirdi." der. Başa çıkamayınca da oğlunun yanına akıllı kişiler, Kârûn hazinesi kadar mal, cihan dolusu asker ve bir mektup verip gönderir. Kafile Cemâbâd'a gelir. Behrâm ve yanındakiler ağırlanır. Tûs'un yazdığı mektup Siyâvuş'a takdim edilince iş anlaşılır. Hurşîd'i Ferahşâd'a vermek istemeyenler bu defa da kızı Behrâm'a vermek için ellerinden geleni yaparlar ve "Verilmiş sözümüz var, olmaz." diyen Siyâvuş'u ikna ederler. Düğün hazırlıkları başlar. Hurşîd bu duruma çok üzülür, kanlı gözyaşları döker. Şiirler yazar, bu şiirlerin cevabını rüyasında, Ferahşâd'ın aynı vezinde yazdığı şiirlerde alır. Ferahşâd hapiste olduğundan bir şey yapamaz, kahrolur.

Günlerden bir gün Mağrip sultanı hastalanır. Oğlunu hapisten çıkarır, meclisi toplar. Ölümünün yaklaştığını, Ferahşâd'a itaat etmelerini söyler ve ruhunu Allah'a teslim eder. Padişah olan Ferahşâd, Âzâd'ı vezir tayin eder. Ülkede hacca gidiyormuş şayiasını yayıp doğuya doğru yola çıkar. Yanında 7.000 yüklü at, deve, katırla 12.000 atlı da vardır. Bu kafiledeki en mühim cevher ise şebçerağdır. Cemâbâd'a varılır ve Hızır İlyas civarında konaklanır. Ateşler yakılır. Hızır İlyas'ın her tarafı aydınlanır. Siyâvuş durumdan haberdar edilir. Padişah ne olup bittiğini öğrenmesi için hemen bir haberci gönderir. Haberci Ferahşâd'a niçin geldiklerini sorunca "Padişah bizi düğüne davet etmiş geldik, gece olduğu için de padişahı rahatsız etmek istemedik." der ve ağır hediyelerle haberciyi uğurlar. Bu arada Ferahşâd, "Nerede kaldın... ve Behrâm'la nasıl ve niçin evlenmeye razı oldun.” anlamına gelen bir şiiri altın kâğıt üstüne gümüş suyuyla yazıp Hurşîd'e gönderir. Dügünün 38. günü Siyâvuş, Ferahşâd'ı yanına çağırtır ve büyük bir törenle karşılar. Ferahşâd diğer hediyelerle birlikte şebçerağı da Siyâvuş'a takdim eder. Kutudan çıkarılan şebçerağ her yeri gündüz gibi aydınlatır. Yemekler yenilir, şaraplar içilir, eğlenilir. Ancak Siyâvuş'u bir düşüncedir alır. Behrâm için dügün yaparken Ferahşâd çıka gelmiştir. Kadıyı ve müftüyü katına çağırtır. Bir taraftan da Ferahşâd'a neden geç kaldığını sorar. Ferahşâd olanları anlatır. Siyâvuş danışma meclisini toplar. Kadı ve müftü "Kız kimi istiyorsa ona verilmeli, şeriatın hükmü budur." derler. Kadı ve müftü Hurşî̂d'e gönderilir. Hurşîd, Ferahşâd'la olan macerası ortaya çıkmasın diye Ferahşâd adını anmadan ince zekasını kullanarak "Taliplerimden hiçbirini tanımıyorum, madem ki babam beni evlendirmek istiyor, Boğa Han'1 öldüren ve tahtı yıkılmaktan kurtaranı seçtim." der. Hurşîd'in söyledikleri Siyâvuş'a iletilir ve oracıkta Hurşîd'le Ferahşâd'ın nikahı kıyılır. Siyâvuş, Behrâm'ın gönlünü alır, türlü hediyeler verir ve memleketine gönderir. Hurşîd ile Ferahşâd'ın hikâyeleri şu beyitlerle biter:

$$
\begin{aligned}
& \text { Ne eksük var ise bitdi arada } \\
& \text { İrişdi ol iki 'âşık murâda } \\
& \text { Murâda irgür iy sultân-1 'âlem } \\
& \text { Dükeli nâ-murâdı vü beni hem }
\end{aligned}
$$

Hüseyin Ayan, "Hurşîd-nâme Konusunun İran Edebiyatı İle Olan İlgisi" başlığıyla, konunun İran ve Arap edebiyatındaki izlerini de sürmüştür. Burada verilen bilgilere göre Şeyhoğlu, bir beyitte eserini Arap edebiyatındaki kıssalara dayandırmaktadır. Ancak H. Ayan, yaptığı araştırmalar neticesinde Arap

TAED 39, 2009, 101-111 
edebiyatında böyle bir hikâyenin varlığına dair kaynaklarda bilgiye rastlayamadığını ve hikâyede İran menşeinin hissedildiğini söyler: "Hurşî́dnâme'deki esas vak'aların Iran (Cem-âbâd)'da geçmesi, Hurşî̀d'in babasının adı (Siyâvuş) annesinin Hitay'lı (Hıtayî Ay Hatun) oluşu, Boğa hanın kişiliğinde belirlenen tipin Turan hükümdarlarını andırması, Behrâm'ın ve babası Tûs'un Şehnâme'deki kahramanlardan Behrâm ile Tûs çağrışımı yapması, Şeb-çeră̆ vs. motif ve epizotlar, bu hikâyenin Iran menşeini hissettirmektedir." (s. 43).

Hikâyedeki kahramanlar, "Hurşîd-nâme Kahramanlarının TarihîEfsanevi Kişilikleri” başlığı altında tek tek tanıtılmış ve bunların Firdevsî'nin Şeh-nâme'sindeki kahramanlarla ortak yanları belirlenmeye çalışılmıştır. Buradan, Hurşîd-nâme ile Şeh-nâme arasında önemli benzerliklerin olduğu ortaya çıkmaktadır. "Hurşîd-nâme'de Savaş Araçları ve Strateji” kısmında ise, hikâyedeki savaşlar, savaş stratejileri ve kullanılan savaş aletleri konu edilmiştir. Buna göre Hurşî̀-nâme'de, Hitây, Mağrip ve Mısır'dan olmak üzere İran'a üç büyük askerî hareket vardır. Bir de bunlara, memleketini korumaya çalışan Siyâvuş'un mücadelesi eklenebilir. Askerî hareketlerde en mühim hayvan at, nakil aracı deve ve katırdır. Fil ve gergedan ünlü savaşçıların kullandığı bineklerdir. Kullanılan savaş aletleri süngü, kılıç, kalkan, gürz, kîş, kemend ve zırhtır. Askerî stratejide ise orduların savaşa başlamadan önce ünlü savaşçılarının tek tek vuruşmaları, savaşların gündüz yapılması, askere cesaret vermek için nutukların irad olunması, vaatlerde bulunulması... gibi hususlar göze çarpmaktadır.

Hikâyedeki eğitim-öğretim konusundan, "Hurşîd-nâme'de Eğitim ve Öğretim" başlı̆̆ 1 altında bahsedilmiştir. Burada verilen bilgilere göre, Hurşîdnâme'de herkese açık ve bugünkü anlamına yakın öğretim kurumları yoktur. Hurşî̀d'in yetişmesinde tutulan yoldan anlaşıldığına göre, saraylarda özel öğretmenler görevlendirilmektedir. Hurşîd, dindar ve yaşlı bir öğretmen olan Pîr Muallim'in elinde bütün ilimleri ve fenleri öğrenmiştir. Konuşması çok güzeldir, nazım ve nesri de değerli inciler gibidir. Beş yaşında başlayan öğrenimi on altı yaşında bitirilmiştir. Eserde, eğitim-öğretimin yanında insanın kaderine tesir eden bâtıl inanışlara da yer verildiği belirtilmiştir.

H. Ayan, "Hurşîd-nâme'de Hurâfelerin İzleri" şeklinde bir başlık açarak eserdeki bazı inanışları konu etmiş ve bunları altı maddede, beyitlerden hareketle açıklamıştır. Bu inanışlar, yeni doğan çocuğun talihinin müneccimlere sorulması, dünyanın su üzerinde olduğuna inanılması, büyü ve büyücülerin elinden olağanüstü işlerin gelebileceği korkusu, Hızır İlyas, sayıların kutsallığı ve şebçerağ gibi inanışlardır. 


\section{A.Ü. Türkiyat Araştırmaları Enstitüsü Dergisi Sayı 39, Erzurum 2009 〜 109 〜 Prof. Dr. Hüseyin AYAN Özel Sayısı}

"Törenler", "Giyimler", “Avlanma ve Avlanmada Yapılan İdmanlar", "Mektup Yazma ve Mektupla İlgili Gelenekler", "Hediye, İhsân ve Saçı Gelenekleri" gibi alt başlıklarla düzenlenen "Hurşîd-nâme'de Gelenekler" kısmı, incelemenin önemli yanlarından birini oluşturur. $\mathrm{Bu}$ gelenekler şu şekilde sıralanabilir: Törenler: Tahta çıkma, şehenşahların katına çıkış ve oradan ayrılış, elçilerin kabulü, şölenler, yeme içme sofraları ve saz heyeti, evlenme ve buna bağlı gelenekler (kız isteme, evlenmeden önce buluşma, evleneceklerin denkliği, erkek tarafının kalın "çeyiz" getirmesi, söz kesimi, düğün, taliplerin seçimi, sağdıç), ölüm ve ölünün defni (başsağlığı ve örtünme, aş yedirme, helalleşme, at kuyruğu kesme). Giyimler: Genç kız ve kadın giyimleri ve bunların yapılışında kullanılan kumaş ve kürkler, kadınların yüzlerini peçeyle örtmeleri, genç erkek elbiseleri, kadınlarla erkeklerin müşterek elbiseleri, fakir ve derviş giyimi. Avlanma ve Avlanmada Yapılan İdmanlar: Hurşîd, Dârü'l-Melek kalesinde gizlice büyütülürken avlanmaya çıar. $\mathrm{Bu}$ avlanmalar bütün gün sürer. Avlanmayla ilgili olarak idmanlar da (av ve savaş oyunları) göze çarpar. Mektup Yazma ve Mektupla İlgili Gelenekler: Mektubun şekli, mektup zarfları, asker toplama mektupları ve dügün davetiyeleri, mektupların takdimi. Hediye, İhsan ve Saçı Gelenekleri: Mesnevide padişahların belirgin vasıfları, cömert ve zengin oluşlarıdır. Hadsiz hesapsız hazinelere sahiptirler, sevdiklerine, kendilerinden yarar beklediklerine ve maiyetindekilere bol bol ihsanlarda bulunurlar. Verilen hediyeler arasında atlar, eyerler, hilatler, kul ve karavaşlar vs. vardır. Hediyelerin verildikleri anlar da önemlidir. Hurşî̀'in yetiştirilmesini üzerine alan Pîr Muallim, vazifesini tamamlayınca Hitâyî Ay Hatun tarafindan nimetlere boğulur. Boğa Han, savaşçılarından Sirhan'ın savaşmak istememesi üzerine onu hediyelerle ikna etmeye çalışır vs.

H. Ayan, İslami kültürün eseri ne şekilde etkilediğini, "Hurşîd-nâme'de İslâm Kültürü” başlığıyla incelemiştir. Buradaki ilk cümleleri şöyledir: "Hurşı̂dnâme, İslâm kültürünün derin tesiri altında yazılmıştır. Eserin baş tarafindaki tevhîd, münâcât, na't, mirâciye ve dört Halîfe (Ebû Bekr, Ömer, Osmân ve Alî)'ye na't-medhiyeler buna delâlet eder." (s. 71). Bu kısımda, Kur'ân-1 Kerîm'den iktibaslar, hadislerden iktibaslar, duâlar ve bedduâlar, danışmalar (müşâvereler), sabır ve tevekkül, kadılık ve müftülük gibi maddeler yer alır.

"Hurşîd-nâme'de Aşk" başlığıyla, eserdeki beşerî ve ilahî aşkın tezahürü üzerinde durulmuştur. H. Ayan burada, beşerî aşkla ilahî aşkın eserde yan yana yürüdügünü ve bunların birbirinden ayrılmasının güçlügünü belirtir. Hurşîd'in güzelliği, bu güzelliği görenin bayılması ve uzun süre kendisine gelememesi, görmeden âşık olma, aşkın ve âşıkların hâlleri, aşk-akıl ilişkisi, aşkın söz, saz ve 


\section{～ 110 ～～İ. AVCI: Şeyhoğlu Mustafa: Hurşîd-nâme (Hurşîd ü Ferahşâa)}

resim yoluyla ortaya çıkışı ve sözün etkisi... gibi konuların ele alındığı bu kısımda, Şeyhoğlu'nun aşk hakkındaki fikirleri de verilmiştir. H. Ayan bunları şöyle sıralar: "1. Aşkın gizli nice dünyalar vardır ki akıl bunlardan aslâ haberdâr olmaz, 2. Aşka boyun eğmeyenler bu âlemlerden bîgânedir, 3. Asşı olmayan insanların kişiliği yoktur, 4. Asşık olmayan insanlar gözden, kulaktan, dilden ve dudaktan lezzet alamazlar, 5. Asşı olmayan insanlar, ne insanın ne de kâinatın sırrını ve seyrini temâşâ edemezler.". H. Ayan bunlardan sonra; "Şâir, bu beş unsurla aşkı târif ederek çeşitli açıklamalar yapmayı da ihmâl etmez. Bu açıklamalarda görülen husus, beşerî aşkın tarifine, ilâhî aşkı karıştırma temayülünün ăğı basmakta olduğudur." (s. 87-88) değerlendirmesini yapar.

Eserin Ü̧̧üncü Bölümü "Hurşîd-nâme'nin Dil ve Üslubu" başlığını taşımaktadır. $\mathrm{Bu}$ bölümde, önce Şeyhoğlu'nun Türkçe ile ilgili olumsuz düşünceleri, buna rağmen eserini Türkçe yazması ve Türk diline ettiği hizmet konu edilmiş; daha sonra eser, "Nazım Tekniği (Vezin, Kafiye, Âhenk)", "Kelime Hazinesi”, "Cümleler" ve "Edebi Sanatlar" açısından değerlendirilmiştir. H. Ayan, aruz veznini Türkçeye uygulama noktasında Şeyhoğlu Mustafa'yı başarılı bulur: "Görülüyor ki Şeyhoğlu Mustafa, arûzun Türkçeye uygulanmasındaki güçlüklerden yılmamış, eserini büyük bir titizlikle yazıp dile hâkimiyetini şâirliğiyle meczedebilmenin güzel örneklerini vermiştir. Hurşîd-nâme, arûzun Türkçeye uygulanmasinda, Süheyl ü Nevbahâr'dan sonra bir nirengi noktası kadar mühim rol oynamıştır." (s. 102). Hurşîd-nâme'de kullanılan kafiye kelimelerinin çoğunluğunun Türkçe olması, özellikle vurgulanan bir husustur. H. Ayan, şairin hiçbir beyitte kafiye sıkıntısına düşmediğini belirttikten sonra, eseri kafiye çeşitleri bakımından örnek beyitlerle incelemiştir. Ayrıca eser, benzer seslerin kullanımı, ses-anlam uyumu vb. açılardan ahenk yönüyle de değerlendirilmiştir. Hurşîd-nâme'deki kelime hazinesi için araştırmac1; "Farsça ve Arapça kelimelerin Türkçe'ye nisbetini tam olarak verebilecek durumda değiliz. Ancak yabancı menşeli kelimelerin Türkçe'ye nisbetinin pek az olduğunu söyleyebiliriz." (s. 108) der. "Cümleler" alt başlığıyla ise eserdeki cümleler yapılarına, yüklemlerine, ögelerinin dizilişine ve manalarına göre incelenmiştir. H. Ayan bu kısımda son olarak eserdeki edebî sanatlardan bahsetmiştir.

Eserin Sonuç bölümünde, incelemeler sonunda ortaya çıkan neticeler bir araya getirilerek maddeler hâlinde verilmiştir. Kısaca özetlemek gerekirse buradaki hususlar şöyledir: Hurşîd-nâme'nin konusu, Firdevsî'nin Şehnâme'sinden alınmıştır. Eser, kuruluş ve vakaların tertibi bakımından da Şehnâme'nin tesiri altındadır. Yine bazı epizotlar, rivayetler, hikâyeler ve efsanelerde de Şeh-nâme'nin etkisi görülür. Hurşîd-nâme'de tasavvufi etki açıkça hissedilir. Hikâye, bir aşkın etrafinda döner. Eser, kelime hazinesi ve dil 
özellikleri açısından eşsiz bir eserdir. İçtimai hayattan örnekler, âdetler ve ananeler önemli yer tutar. Bazı kısımlarda didaktik kaygı ağır basar. Hurşîd-nâme şekil bakımından kusursuz bir mesnevidir.

Sonuç bölümünden sonra sırasıyla beş sayfalık bir Bibliyografya, Transkripsiyon Iş̦âretleri ve Şeyhoğlu'nun eserlerinden biri olan Kenzü'l-Küberâ ve Mihekkü'l-'Ulemâ'dan iki varağın fotokopisi yer almaktadır. Bibliyografya kısmına bakıldığında, araştırmacının eseri hazırlarken konuyla ilgili yerli ve yabancı temel kaynakları kullanma konusunda titiz davrandığı görülür. $\mathrm{Bu}$ kısımda, yararlanılan sözlükler ayrı bir başlıkla verilmiştir.

Eserin Dördüncü Bölümü, dört nüshanın karşılaştırılmasıyla ortaya konan 7903 beyitlik Hurşîd-nâme'nin tenkitli metnine ayrılmıştır.

Araştırmacı eserinin sonuna, çoğunluğu Türkçe kelimelerden oluşan bir Sözlük (Metinde Rastlanan Eski Kelimeler) eklemiştir. H. Ayan, bu sözlükle ilgili olarak eserin kelime hazinesini değerlendirdiği kısımda, asıl niyetinin bir kelime dizini hazırlamak olduğunu ve bu konuda bir hazırlık yaptığını, eserde 65.000 kelime tespit ettiğini, ancak çalışmanın bir dil çalışması olmaması nedeniyle bu düşüncesinden vazgeçtiğini belirtir. Elli sayfa tutarındaki bu sözlük, hem eserin anlaşılması hem de yazıldığı dönemin kelime hazinesinin ortaya çıkarılması açısından oldukça önemlidir.

Çalışmanın son kısmı Konu Dizini (Metinde Geçen Konularla Illgili)'ne ayrılmıştır. Burada, eserde geçen belli başlı konular maddeler hâlinde beyit numaralarıla birlikte verilmiştir.

Hüseyin Ayan, kısaca üzerinde durduğumuz bu çalışmasıyla, XIV. yüzyıl Türk edebiyatının hem dil açısından hem de edebî açıdan oldukça önemli bir eserini Türk dili ve edebiyatıyla ilgilenenlerin istifadesine sunmuştur. Tenkitli metin çalışmalarında bir eserin nüshalarının tespiti, bu nüshaların elde edilmesi, metnin kurulması... gibi konuların zorlukları alanın uzmanlarınca malumdur. Hurşîd-nâme'nin hazırlandığ 1 dönemin şartları düşünüldüğünde bu zorlukların bir kat daha arttığı görülmektedir. H. Ayan, böyle hacimli bir eserin tenkitli metnini hazırlayıp vukufla inceleyerek Türk dili ve edebiyatına büyük bir hizmette bulunmuştur. 